\title{
Galactosyltransferase Activities in Human Sera of Various Diseases
}

\author{
Tatsuya Motoki, Takeo KAWASE, Shin'ichi OHTA, Hajime TAKIgAwA, \\ Yasushi SHIRATORI, Tetsuo KATAMOTO, Tohru INAGAKI, \\ Ken'ichi OKano, Akira Terano, Kazunori Matsumoto, \\ Satoru MURAO and Kijuro NOMURA* \\ Second Department of Internal Medicine, Faculty of Medicine, Tokyo University \\ Hongo 7-3-1, Bunkyo-ku, Tokyo 113 \\ *Department of Internal Medicine, Chigasaki City Hospital \\ Chigasaki 50, Chigasaki-shi, Kanagawa Pref. 253 \\ Received November 15, 1980
}

\begin{abstract}
Recently galactosyltransferase has been noted as a new tumor marker. In this report galactosyltransferase activity was measured in sera of various diseases including malignant tumors and the levels of the enzyme activities were compared. The levels of the enzyme were higher in sera of malignant tumors and liver diseases than those in sera of other diseases. In malignant tumors little organ specificity was found with respect to the levels of galactosyltransferase activities. The levels of the enzyme were considered to have no relation to carcinoembryonic antigen or $\alpha$-feto protein. On the other hand, in liver diseases the levels of the enzyme were correlated to the severity of liver damage. Therefore, it is reasonable to presume that the elevation of serum galactosyltransferase activity is caused chiefly by malignant tumors and liver damage.
\end{abstract}

Key Words: galactosyltransferase, tumor marker, serum level, malignant tumor, liver disease

Galactosyltransferase activity has been reported to be present on the intracellular and cell surface membranes of various cell types ${ }^{1), 2}$. Recently Podolsky was able to detect a cancerspecific isoenzyme of galactosyltransferase in sera of cancer patients by means of discontinuous polyacrylamide gel electrophoresis ${ }^{3)}$. Galactosyltransferase activities in sera of other diseases, however, have not been studied thoroughly, we studied the activities of this enzyme in sera of various diseases in this paper.

\section{Methods and Materials}

Galactosyltransferase activity was measured by the method of $\mathrm{Kim}^{4)}$. Glycoprotein acceptor in this study was fetuin minus terminal sialic acid and penultimate galactose residues. The acceptor was prepared as described by Spiro $^{5}$. Fetuin ( $500 \mathrm{mg}$; Gibco, Grand Island, N.Y., USA) was suspended in $25 \mathrm{ml}$ of $0.1 \mathrm{M} \mathrm{H}_{2} \mathrm{SO}_{4}$ and incubated at $80^{\circ} \mathrm{C}$ for 60 minutes. The hydrolysate was neutralized by the addition of $1 M \mathrm{NaOH}$ and then dialysed against water at $4^{\circ} \mathrm{C}$. To the sialic acid-free fetuin was then added $50 \mathrm{~m} l$ of $0.02 M$ sodium metaperiodate in $0.1 \mathrm{M}$ sodium acetate buffer, $\mathrm{pH} 4.5$, and incubated for 24 hours in the dark at $4^{\circ} \mathrm{C}$. The reaction was stopped by the addition of $7.5 \mathrm{~m} l$ of glycerol and the mixture was then dialysed against water at $4^{\circ} \mathrm{C}$. To this non-diff usable material was added $50 \mathrm{~m} l$ of $0.45 M \mathrm{NaBH}_{4}$ in $0.45 \mathrm{M}$ potassium tetraborate, $\mathrm{pH} 8.0$, for 13 hours at $4^{\circ} \mathrm{C}$. The reaction was stopped by adjusting the $\mathrm{pH}$ to 5.0 by the addition of $1 \mathrm{M}$ acetic acid and the material was then dialysed against water at $4^{\circ} \mathrm{C}$. The non-diff usable, galactose-free fetuin was then freeze-dried. The fetuin acceptor thus obtained was used as a stock solution containing $1.5 \mathrm{mg}$ of acceptor/ $20 \mu l$. UDP- ${ }^{3} \mathrm{H}$-galactose (455 GBq $(12.3 \mathrm{Ci}) /$ mmol) was obtained from New England Nuclear. A stock solution $(704 \mu \mathrm{mol} / l)$ was prepared to a final specific activity of $3.7 \mathrm{GBq}(0.1 \mathrm{Ci}) / \mathrm{mmol}$ using unlabelled UDP-galactose obtained from Sigma Chemical Company. The assay mixture included $20 \mu l$ serum, $20 \mu l$ fetuin acceptor stock 
solution, $15 \mu l$ ( $37 \mathrm{kBq}(1 \mu \mathrm{Ci})$ ) UDP- ${ }^{3} \mathrm{H}$-galactose

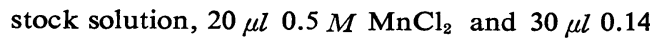
$M$ sodium cacodylate, $\mathrm{pH} 7.2$, and $0.22 \mathrm{M} \mathrm{NaCl}$. The mixture was incubated for 60 minutes at $37^{\circ} \mathrm{C}$. The reaction was terminated by addition of $5 \%$ phosphotungstic acid and $2 \mathrm{M} \mathrm{HCl}$. The precipitate was collected on a glass microfiber filter, washed with $5 \%$ phosphotungstic acid-2 $M$ $\mathrm{HCl}$ and then ethanol. The retained material was placed in a vial containing $10 \mathrm{ml}$ of a scintillator ( $4 \mathrm{~g}$ of 2,5-diphenyloxazole, $50 \mathrm{mg}$ of 1,4-bis-(5-phenyloxazole-2-yl)benzene per liter of toluene). The vial was counted for radioactivity in a liquid-scintillation spectrometer and corrected for quenching.

Carcinoembryonic antigen in serum was measured by radioimmunoassay of sandwich method of Dainabott Radioisotope Laboratories (normal value below $2.5 \mathrm{ng} / \mathrm{m} l$ ) and $\alpha$-feto protein was measured by radioimmunoassay (normal value below $10 \mathrm{ng} / \mathrm{ml}$ ).

Serum samples were obtained from 174 patients with various diseases in our clinic. Serum was stored at $-70^{\circ} \mathrm{C}$ until used. The samples were measured for galactosyltransferase activity in two separated occasions. Data obtained in the same occasion of measurement were compared each other.

\section{Results}

Galactosyltransferase activity was measured in sera of cases with various diseases. Comparison of the data was shown in Fig. 1. As Kim noted the increase of the level of this enzyme in sera of liver diseases, cases who had no abnormality of liver function were selected as disease groups other than malignancy and liver cirrhosis for comparison. It can be seen on Fig. 1 that the levels of the enzyme in malignant tumors and in liver cirrhosis were significantly higher than those in other diseases. Among the cases other than malignant tumors and liver diseases there were no significant differences in the levels of the enzyme.

Then, the levels of galactosyltransferase activities were compared among various malignant tumors, such as 4 cases of primary liver cancer, 5 cases of biliary cancer, 5 cases of pan creas cancer, 12 cases stomach cancer, 6 cases

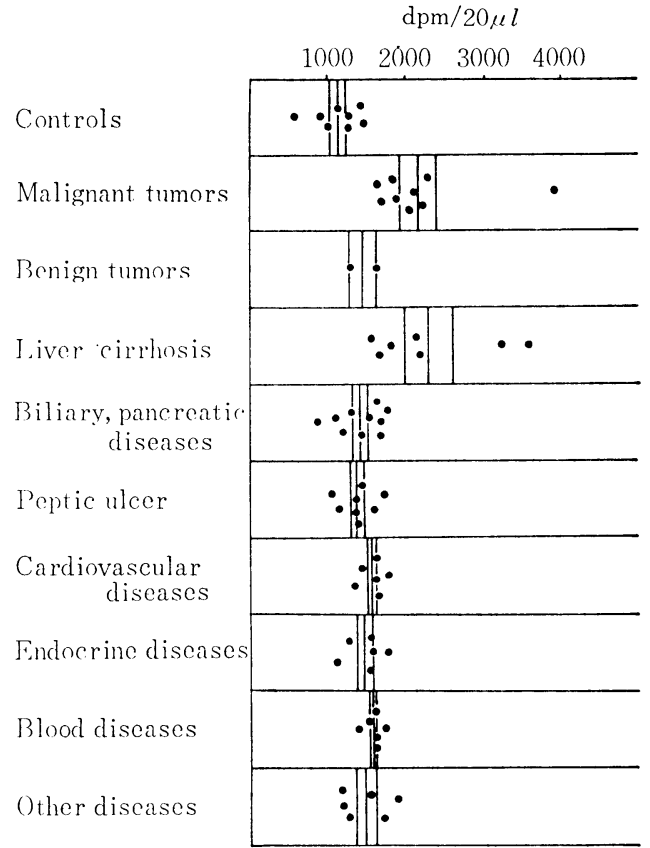

Fig. 1 Galactosyltransferase activities in sera of various diseases. (mean \pm S.E.M.)

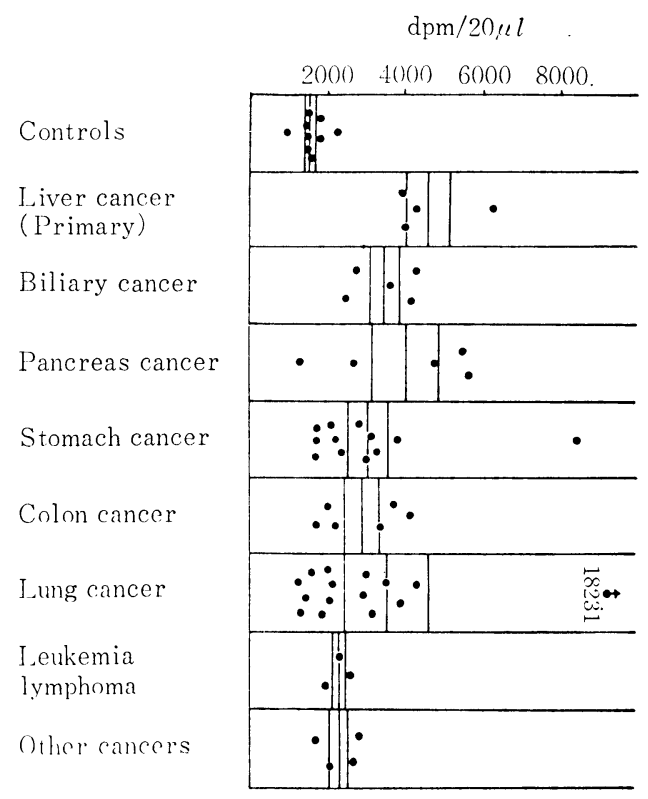

Fig. 2 Galactosyltransferase activities in sera of malignant tumors. (mean \pm S.E.M.)

colon cancer, 15 cases lung cancer, 2 cases leukemia, a case malignant lymphoma and 4 cases other malignant tumors. The results were shown 


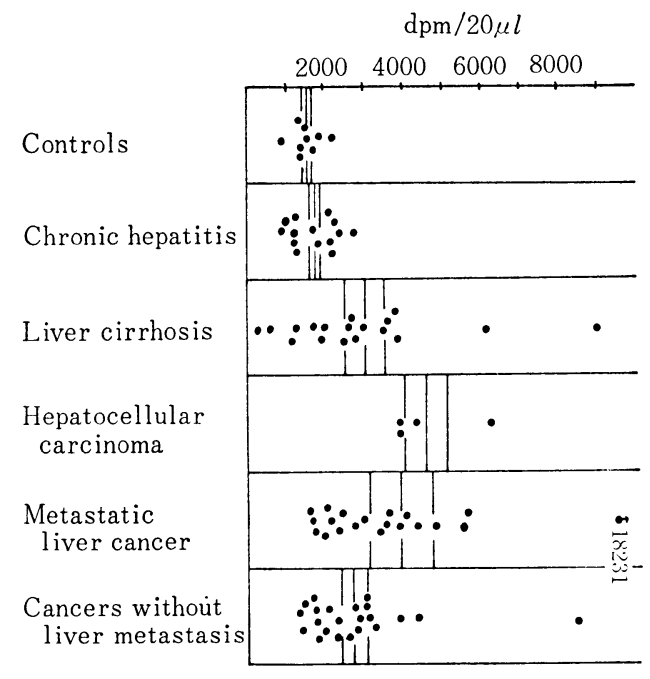

Fig. 3 Galactosyltransferase activities in sera of chronic liver diseases and liver tumors. (mean \pm S.E.M.)

in Fig.2 and partly in Fig.3. There were little differences among the levels of the enzyme in various malignant diseases. As shown in Fig. 3 the levels in primary and metastatic liver tumors were slightly higher than those in malignant tumors who had no liver involvement. But this difference was not significant. Thus, organ specificity was not confirmed in levels of galactosyltransferase of malignant tumors.

On the other hand, the levels of galactosyltransferase activities were compared among chronic liver diseases (Fig.3). The levels in liver cirrhosis were significantly higher than those in chronic hepatitis and were as high as in malignant tumors. In chronic liver diseases levels of the enzyme were directly proportional to certain data of liver function tests such as serum albumin, zinc sulfate test and indocyanine green 15 minutes retention rate. In the groups other than liver diseases or malignant tumors, the levels in cases with liver dysfunction were higher than those in cases without liver dysfunction.

Carcinoembryonic antigen and $\alpha$-feto protein in sera of cases in this report were also measured. Data of these tumor markers were studied on their relation to levels of galactosyltransferase activities. There were no correlation, however, between the levels of this enzyme and those of the above tumor markers. Therefore, galactosyltransferase in serum was considered to have no relation to them.

\section{Discussion}

Galactosyltransferase activity has been identified with intracellular membranes and cell surface membrane of various cell types ${ }^{1), 2)}$. In an experiment of Chatterjee the most of this enzyme activity was associated with the plasma membrane vesicles ${ }^{6)}$. Several laboratories have reported alterations in levels of certain glycosyltransferases associated with the neoplastic state. Galactosyltransferase level, however, was found elevated in plasma of certain cancer patients and not elevated in other cancer patients ${ }^{4)}$, 7). Recently Podolsky reported that a tumor specific isoenzyme of galactosyltransferase was detected in sera of cancer patients ${ }^{3)}$. This finding will provide a useful mean for the elucidation of the above discussion. Total galactosyltransferase activities in sera of various diseases including malignancy, however, have not been studied thoroughly. In this report we measured the levels galactosyltransferase activities in sera of various diseases and the data were compared each other.

In our results the levels of galactosyltransferase activities in malignant tumors and in liver cirrhosis were significantly higher than those in other various diseases. No significant difference was found between the levels of the enzyme in malignant tumors and those in liver cirrhosis. In malignant tumors the levels in primary and metastatic liver cancer were slightly higher than those in malignant tumors without liver involvement. But the difference was not significant. Among all groups of malignant tumors superiority of the levels of the enzyme was not noted in malignant tumors of any specific organ. Thus, organ specificity in the level of galactosyltransferase activitiy was not considered to be present in malignant tumors. On the other hand, the levels of the enzyme in liver cirrhosis were significantly higher than those in chronic hepatitis. In these chronic liver diseases the level of the enzyme was proportional to the 
severity of liver dysfunction. In groups of other diseases the levels of the enzyme in cases with liver dysfunction were higher than those in cases without liver dysfunction. Therefore, it might be thought that galactosyltransferase activity is increased in serum when the liver is injured and that some aspects of the severity of liver damage would be expressed by the level of this enzyme. As Kim described previously"), galactosyltransferase was considered to be released into circulation when the liver, which was rich in galactosyltransferase, was injured.

Carcinoembryonic antigen and $\alpha$-feto protein are considered to be produced in malignant cells and be shedded into circulation. Some parts of galactosyltransferase might be released in the similar manner from malignant cells. Then, the relation of galactosyltransferase to the above tumor markers was studied. The serum level of carcinoembryonic antigen or $\alpha$-feto protein, however, was not correlated to the level of galactosyltransferase activity when studied individually in each of the subjects. Therefore, galactosyltransferase activity in serum was considered to have no relation to carcinoembryonic antigen or $\alpha$-feto protein.

Podolsky was able to detect a cancer-specific isoenzyme of galactosyltransferase in sera of cancer patients ${ }^{3)}$. As this isoenzyme is considered to be a new tumor marker which is nonspecific for organ, new informations for elucidation of malignancy would be expected to be obtained by investigating it.

\section{Acknowledgment}

We thank Dr. Tadao Terao of the National Hygienic Laboratory for his interest and advice in this investigation.

\section{References}

1) Schachter, H., Jabbal, I., Hudgin, R.L., Pinteric, L., McGuire, E.J. and Roseman, S.: J. Biol. Chem., 245, 1090 100 (1970)

2) Weiser, M.M.: ibid., 248, 2542 48 (1973)

3) Podolsky, D.K., Weiser, M.M., Isselbacher, K.J. and Cohen, A.M.: New Engl. J. Med, 299, 703 05 (1978)

4) Kim, Y.S., Perdomo, J. and Whitehead, J.S.: J. Clin, Invest., 51, 2024 39 (1972)

5) Spiro, R.G.: J. Biol. Chem., 239, 567 73 (1964)

6) Chatterjee, S.K. and Kim, U.: J. Natl. Cancer Inst., 58, 273 80 (1977)

7) Bhattacharya, M. Chatterjee, S.K. and Barlow, J.J.: Cancer Res., 36, 2096 101 (1976)

\title{
各種疾患例における血清 galactosyltransferase 活性の検討
}

\author{
本木達也, 川瀬建夫, 太田慎一, 滝川一, 白鳥康史, 片本哲郎, 稲垣 徹, \\ 岡野健一, 寺野 彰, 松本和則, 村尾 覚, 野村喜重郎* \\ 東京大学医学部第 2 内科 113 東京都文京区本郷7-3-1 \\ *茅ヶ崎市立病院内科 253 神奈川県茅ヶ崎市茅ヶ崎 50
}

\begin{abstract}
最近，腫瘍マーカーの一つとして注目されている，ガラクトシルトランスフェラーゼの各種疾患 に扎ける血清中の活性について検討した。対象は当院患者 174 例である。本酵素の活性は悪性腫瘍 と肝疾患において他疾患よりも高かった。悪性腫瘍での血清レベルは臟器による差は明らかでなか った。また，本䤉素の活性は各例に拈ける血清中の CEA あるいは $\alpha$-feto タンパク濃度と相関せ ず，これらとは無関係である。一方，肝疾患においては本酵素活性のレベルは肝障害の程度に比 例した。以上から，血清ガラクトシルトランスフェラーゼ活性の上昇は，抒もに悪性腫瘍と肝障害 の存在する場合に起こると思われる。
\end{abstract}

